\title{
Study on Audit Failure of Registered Accountants: Take Enron event as an example
}

\author{
Shuang Wang \\ School of North China Electric Power University, Baoding 071000, China
}

Keywords: audit, failure, Enron event

\begin{abstract}
Since 21st century, the substantial audit failure cases occur constantly. The disclosure of a series of audit scandals has caused a worldwide audit credit crisis. Therefore, it is very important to explore the causes of audit failure and propose solutions. In this paper, we take Enron event as an example to analyze the causes of audit failure and to find solutions to improve the credibility of audit report.
\end{abstract}

\section{Introduction}

Enron was founded in 1985, as one of the world's biggest energy dealer.In 2000, it was ranked seventh in Fortune magazine's "top 500". On October 16 2001, Enron Corp announced that it has third quarter loss which was amounted to $\$ 618$ million. The U.S. Securities and Exchange Commission Enron Corp began to conduct a formal investigation to Enron on October $31^{\text {st }}$. On November 8, Enron submitted to the US Securities and Futures Commission to confirm the false account: from 1997 to 2001, a total of \$ 586 million in profits, and it did not account for huge debts. Enron's outbreak, one of the world's largest energy companies and one of the world's top five accounting firms have closed down simultaneously. It is regrettable.

\section{Analysis on audit failure factors}

\subsection{Independence}

The nature of the audit is an independent agent of economic supervision activity. Independence includes formally independence and substantive independence.

\subsection{Formally independent}

The formally independence means that the auditor must have no special interest relationship with the principal. Taking Enron event as an example, Arthur Andersen Enron Corp non audit service charges \$27 million,but the audit fee was 25 million. When the audit fee is less than the non-audit service charges, the formal independence can not be satisfied. At the same time the connection relation also seriously affected the audit independence.Enron's senior executives, who are in charge of finance, are from Arthur Andersen.

\subsection{Substantive independence}

Substantive independence means that the auditor must strictly maintain the independent mental state in the whole process. And making professional judgment doesn't rely on and submit to external pressure. In 1997, Arthur Andersen audit Enron's annual financial statements report.It reminded that certain matters should be adjusted..If so, the company's profit would reduce by $\$ 50$ million.Enron did not agree.So Arthur Andersen had to compromise. We can image whether Enron put pressure on Arthur Anderson.

\subsection{Professional norms of registered accountants \\ 2.5 Insufficient professionalism}

Enron formed a huge and complex enterprise organization through capital restructuring.The more and more enterprises established, the leverage effect of financing is more lager. Enron company finally developed more than 3,000 affiliates. Management created complex financial structures, even Wall Street analysts and accounting professors are hard to understand . Therefore, the CPA must have the corresponding professional competence, and due attention. Maintain professional skepticism, use professional knowledge, skills and experience to effectively complete the audit business. The 
registered accountant failed to identify the " business risk" and " fraud risk" behind the rapid growth of Enron.Is a serious manifestation of professional deficiencies.

From the perspective of China, risk-oriented audit has not been applied in the practice of independent.China is still in the transition stage of from transaction-based auditing to system-based auditing .The transaction-based auditing takes the book as the starting point.And it aims to the authenticity of accounting data. It uses more judgment sampling, that is, the audit mainly from the subjective judgment of CPA. In the case of large-scale enterprises and economic business more complex circumstances.It is easy to be material misstatement. The system-based audit starts with the internal control of the enterprise to. Testing and evaluating the effectiveness of internal control to determine the nature and scope of the substantive testing.However, with the increase of enterprise risk and uncertainty, institutional basis audit may still be a big deviation. In view of this, technical reasons are still a major factor affecting the quality of the audit.However, with the increase of enterprise risk and uncertainty, the system foundation audit may have larger deviation. Therefore, the technical reason is still a major factor affecting the audit quality.

\subsection{Moral crisis}

At present, there is no uniform standard of punishment for certified auditors' false audit reports. The behavior of certified public accountants is mainly subject to its moral concept. But in the rapid economic development today, people's moral values are increasingly blurred. In the face of huge economic benefits, PA is also difficult to do without losing themselves. Enron event, Arthur Andersen is in violation of his industry as a certified public accountant.

\section{Institutional factors}

The accepted global best American accounting standards, with the outbreak of Enron, exposed many problems. Before the Enron event, the American CPA industry association only requested the auditors to change every seven years.But there is no clear and specific requirements for the rotation of accounting firms, which has a certain impact on the assurance of audit quality. Before the Enron incident, Arthur Andersen certified public accountants had provided Enron company for 16 years of audit service. Such a long agreement,it is easy to achieve internal collusion agreement, which is seriously affect the independence of Arthur Andersen audit. And, the long term audit term, the auditors are easy to relax.

The Chinese accounting theory has not given much attention to the audit rotation.After continuously serious financial fraud and audit failure cases appear. Although China does not make clear regulations of accounting rotation.It has clearly specified that the CPA should periodically rotate the auditor of audit project.

On the other hand, different from other countries, most of the Chinese accounting firms are registered in the form of a limited liability company. When the fraud is found, the CPA only assume limited liability with the limit of registered capital. When the CPAs believe that the loss is far lower than the economic benefits of fraud, fraud becomes the inevitable result.

\section{Size of the firm and pressure from customers}

Scholar Dionne's study shows that the size of the firm is proportional to the behavior of the customer's false report. That is to say, the bigger the scale can resist the unreasonable demands from the customer. At present, the scale of China's accounting firms are scattered and size varies. Larger firms are concentrated in several economically developed cities. The size of the offices of the underdeveloped areas is generally small, which is difficult to refuse the unreasonable demands of the audited. 


\section{Recommendations to improve audit quality}

\subsection{From the firm and the CPA perspective}

\subsection{The CPA should be independent, objective and impartial}

Independence is the soul of CPA to carry out business. Accountant should practice, strive to follow the truth of the truth. Auditors issuing audit opinions are not affected by prejudice, conflicts of interest and the impact of others. The huge non-audit service seriously affect the independence. The accounting firm should be prohibited to provide non-audit services while providing audit services to a company. And encourage accounting firms to cross the audit and non-audit business of listed companies or cross-check. So the independence of the accountant can be guaranteed.

\subsection{CPA shall maintain professional competence and due suspicion}

The ability to practice is the most basic requirement for auditors. Auditors should continue to receive follow-up education and strengthen their work experience.

In the face of today's complex audit environment, auditors must constantly improve their professional competence.At the same time,they should keep suspicoins attitude. Obtain the reliable audit evidence, use a variety of audit procedures to evaluate the audit evidence.Not all of the information can be valid evidence.

\subsection{Expansion of the size of accounting firms}

Chinese accounting firms are generally small with poor competitiveness. As mentioned above, the size of the firm is proportional to the ability to maintain independence. Therefore, the firm can expand the scale in a voluntary premise through strong joint, absorption and consolidation. The expansion of the scale can obtain more customer resources. On one hand, it can enhance the initiative to negotiate with audited units, resist the pressure from audited units, and maintain independent of the auditor. On the other hand, we can improve the competitiveness of the firm, reduce the operating cost, and improve the profitability.

\subsection{From the government perspective}

Enron event shows that rules based on specific rules are always lagging behind business innovation. Businesses are easy to drill through loops through various arrangements. The system is difficult to achieve perfection. Aimed to the emergence problems, on one hand, the Chinese government should strengthen the penalties to the audit fraud cases, government should play a harsh role; on the other hand, the government should improve the relevant laws and regulations, such as to strengthen the clarification of the audit rotation system .

\section{Summary}

Through the disclosure of Enron event, we find that auditing plays a very important role in the shareholders, even public investors. After analysis, we get the factors which influence the audit quality.Then from the perspective of CPA,government and accounting firm. We proposed the measures to improve the quality of auditing.

\section{References}

[1]. He Xuefei. (2008). The Responsibility of False Accounting and Governance. Journal of Central South University of Forestry \& Technology (Social Sciences),2(4): 69-72.

[2]. Shen Zhenyu, Wang Jinsheng and Xue Shuang. (2004). Orientation Conflict of Accounting Standards Setting.

[3]. Journal of Finance and Economics, 30(6): 77-85. 